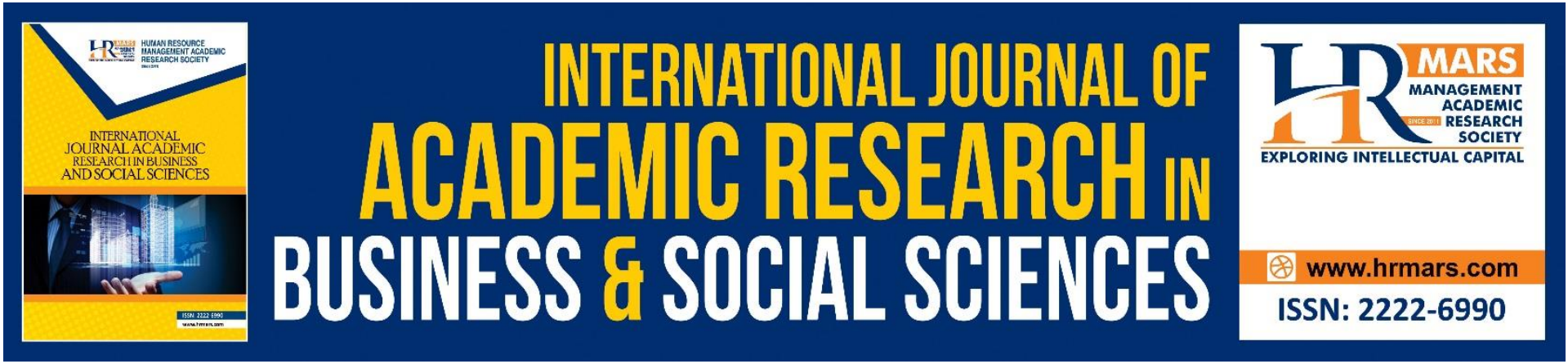

\title{
A Study of Personal Values, Sociocultural Adaptation And Subjective Well-Being From the Perspective of Refugees in the Time of Covid19 Pandemic
}

Nor Lelawati Jamaludin, Nurul Salizawatee Mahpar, Syarifah Farradinna, Norina Ahmad Jamil, Melissa Faisal, Eshaq Ali Barna

To Link this Article: http://dx.doi.org/10.6007/IJARBSS/v11-i5/9738

DOI:10.6007/IJARBSS/v11-i5/9738

Received: 10 April 2021, Revised: 29 April 2021, Accepted: 14 May 2021

Published Online: 26 May 2021

In-Text Citation: (Jamaludin et al., 2021)

To Cite this Article: Jamaludin, N. L., Mahpar, N. S., Farradinna, S., Jamil, N. A., Faisal, M., \& Barna, E. A. (2021). A Study of Personal Values, Sociocultural Adaptation And Subjective Well-Being From the Perspective of Refugees in the Time of Covid19 Pandemic. International Journal of Academic Research in Business and Social Sciences, 11(5), 598-616.

Copyright: (c) 2021 The Author(s)

Published by Human Resource Management Academic Research Society (www.hrmars.com)

This article is published under the Creative Commons Attribution (CC BY 4.0) license. Anyone may reproduce, distribute, translate and create derivative works of this article (for both commercial and non-commercial purposes), subject to full attribution to the original publication and authors. The full terms of this license may be seen at: http://creativecommons.org/licences/by/4.0/legalcode

Vol. 11, No. 5, 2021, Pg. 598 - 616

http://hrmars.com/index.php/pages/detail/IJARBSS

JOURNAL HOMEPAGE

Full Terms \& Conditions of access and use can be found at http://hrmars.com/index.php/pages/detail/publication-ethics 


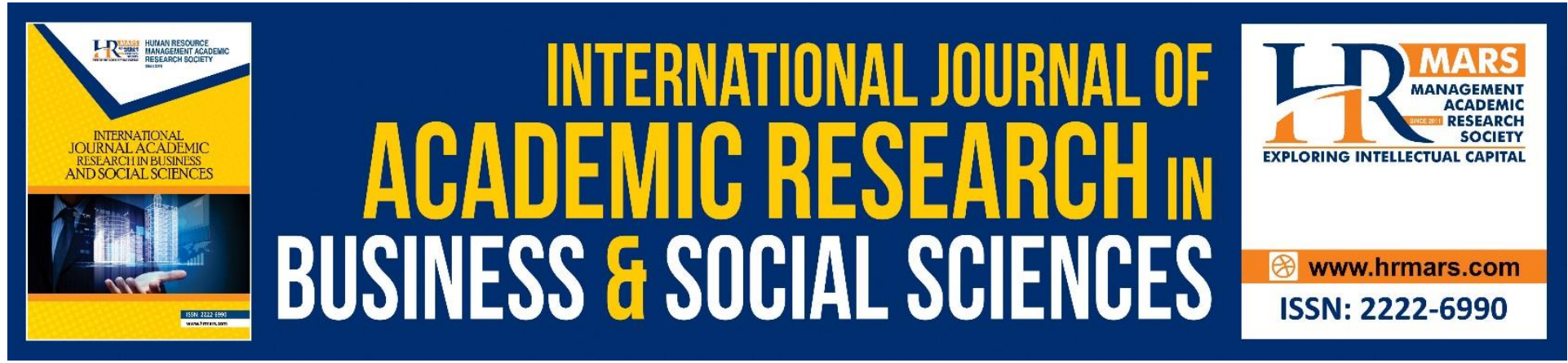

\section{A Study of Personal Values, Sociocultural Adaptation And Subjective Well-Being From the Perspective of Refugees in the Time of Covid19 Pandemic}

Nor Lelawati Jamaludin

Faculty of Business and Management, Universiti Teknologi MARA, Puncak Alam Selangor.

Email: norlelawati0019@uitm.edu.my

Nurul Salizawatee Mahpar

Faculty of Business and Management, Universiti Teknologi MARA, Puncak Alam, Selangor, Malaysia

Email: salizawatee@uitm.edu.my

Syarifah Farradinna

Fakultas Psikologi, Universitas Islam Riau, Jalan Kaharuddin Nasution no. 113,

Pekanbaru, 28284, Riau, Indonesia

Email: syarifah.farradinna@psy.uir.ac.id

Norina Ahmad Jamil

Faculty of Business and Management, Universiti Teknologi MARA, Puncak Alam, Selangor, Malaysia

Email: norina0048@uitm.edu.my

\section{Melissa Faisal}

Faculty of Business and Management Universiti Teknologi MARA, Melaka

Email: nurmelissa@uitm.edu.my

\section{Eshaq Ali Barna}

United Nations High Commissioner for Refugees (UNHCR), 570 Jalan Bukit Petaling, 50460

Kuala Lumpur, Malaysia

Email: eshaqbarna@gmail.com

\section{Abstract}

The goals of the present study were to test the relationship between personal values (i.e., self-transcendence and self-enhancement) and subjective well-being and the mediation of 
this relationship by sociocultural adaption among a sample of Afghan refugees $(N=381)$ during COVID19. The data was analysed using SPSS 25. Results show that self-transcendence was a significant predictor of subjective well-being, even by controlling for sociocultural adaptation. Sociocultural adaptation did not significantly mediate the positive relationship between refugees' self-transcendence and subjective well-being. This research provides a novel understanding from the psychological perspectives of refugees' well-being in time of crisis. We anticipate many new insights with the recent flourishing of research on personal value-subjective well-being relations, and with the additional inclusion of sociocultural adaptation.

Keywords: Personal Values, Sociocultural Adaptation, Subjective Well-Being, Refugees, COVID19

\section{Introduction}

The interest in this study starts from the realization of the value of refugees' experiences in adapting to a new nation especially in times of crisis. An outbreak of novel corona virus (COVID19) infection occurred in China at the end of 2019, followed by a brief period of continuous spread around the world. The World Health Organization increased its pandemic alert level to the highest level on 12 March 2020. Following this, the Malaysian Government has taken a range of preventive steps, including the promotion of public awareness of the virus through mass media, patient isolation, and near contact individual quarantine. In addition to this, the world has undergone massive changes in response to the death threat from COVID19, with the potential for even greater social transformation (Ahmad, Mueller \& Tsamakis, 2020).

Following this, The United Nations High Commissioner for Refugees (UNHCR) in Malaysia has expressed deep concern about this unprecedented pandemic and its effect on refugees in Malaysia (UNHCR, 2020). On this basis, current research has been carried out on the premise that the new COVID19 causes protection dysphoria among refugees. In addition, the absence of opportunity and instability in the host country is known to affect the attitudes and wellbeing of refugees (Franks, Gawn, \& Bowden, 2007).

Our attitudes and sociality are generally believed to be influenced by what we consider essential in life-that is, by our beliefs (Boer, \& Fischer, 2013). The ideals were also inseparable from the replacement of conventional values, social power, and realized impotence (Lau \& Thomas, 2008). In addition, Boer and Fischer (2013) have indicated that to understand support for healthcare, justice, and other socially significant issues, personal values seem to be especially important. No theoretical structure to date describes how personal values apply to a wide range of pandemic social cultural adaptation and well-being. In addition, new legislation is required to reduce the mental health effects of COVID19 at national and local levels and improve current community mental health programs.

This study offers a starting point where it is possible to design the government service delivery, institutional capability and program effectiveness. This will also raise further concerns on how the objectives of the refugee resettlement program can be questioned and/or extended, both economically and socially, to include the goal of integration. If the mental health needs of refugees are not addressed effectively, social structures and peace will be adversely affected, effectively hindering long-term economic development. 
Researchers have indicated that although the real extent of COVID19's mental health burden is just starting to surface, the impacts are likely to continue well after the pandemic has been resolved (Otu, Charles, \& Yaya, 2020). In addition, studies have consistently found that changes during the pandemic have adverse effects on immigrants and refugees' mental health (Wickramage, Gostin, Friedman, et al. 2018; Safak-Ayvazoglu, et al. 2018; SafakAyvazoglu \& Kunuroglu, 2019).

Hence in sociology and social psychology, interest scholars have assumed universal connections between values and other psychological structures such as characteristics and strategy (Welzel \& Inglehart, 2010; Welzel, Inglehart, \& Klingemann, 2003; Roccas, Sagiv, Schwartz \& Knafo, 2002). Schwartz (1992) indicated that values apply to other structures consistently. In addition, cultural psychology has based a lot on the idea that culture and ecology can lead to different minds (Henrich, Heine, \& Norenzayan, 2010; Norenzayan \& Heine, 2005; Shweder et al., 1997). Further, recent neuroscience research also indicates cross-cultural variations in brain responses to social stimuli (Ames \& Fiske, 2010), but in the era of crisis and pandemic, minimal study has tested it. Therefore, variability is much more probable than universality in these relations. In the crisis era, we introduced a new system of value-adaptation-well-being relations focused on an integrated taxonomy. We believe that this result will help strengthen the refugee program, strategy and law enforcement that helps to fulfill the 2030 agenda of the United Nations Sustainable Development Goals (SDGs).

In addition, this research was done to bridge the gap in the literature and provide an integrated approach to understanding the phenomenon and analyze the theoretical and empirical evidence on the relationships described.

\section{Mapping the Current Scenario for Refugees Community}

The United Nations High Commissioner for Refugees (UNHCR) is aware of the difficulties and information gaps between the organization and the partner states and the refugees, especially in times of crisis, with the current increase in the number of refugees in Malaysia (UNHCR, 2020). Moreover in popular discourse, the portrayal of refugees is still discouraging; they are frequently synonymous with delinquency, separation and resistance to change (Hagendoorn, 1991). While refugees from Afghanistan are found in different parts of the world, they appear to be concentrated in the largest urban center, which is now the center of the COVID19 pandemic in most countries. In addition, adjusting to a new culture may be a challenging and stressful process for refugees, even though this experience in the host country can provide opportunities to encourage intercultural competence and expand one's worldview (Rienties, Luchoomun, \& Tempelaar, 2013; Berry, 2005; Ward, Bochner, \& Furnham, 2001). There is substantial evidence that migration experiences vary in degrees and ways across a range of communities, including visitors, foreign students, international business people, migrants and refugees (Ward, Bochner, \& Furnham, 2001). Because of the forced nature of their immigration, refugees face a comparatively more complicated and less productive adaptation process compared to immigrants (Berry et at., 1997). While other studies indicate that refugees have complied with local government policies, they are still seen as unable to achieve psychological and mental health well-being (Walther, Fuchs, Schupp, \& von Scheve, 2020). Furthermore, the literature on refugees resettling in host communities suggests that any history of trauma, along with the accumulation of physical problems, has an effect on both mental health and well-being, especially among refugees 
reporting higher levels of symptoms of depressive and post-traumatic stress disorder (PTSD) (Nesterko, Jäckle, Friedrich, Holzapfel \& Glaesmer, 2020).

Healthcare costs remain a major problem for refugees, with 50 percent of refugees unable to access healthcare due to inaccessibility (UNHCR, 2018). This is unsurprising, given that the government does not provide welfare for refugees and that foreign aid and support for NGOs is insufficient to cover basic needs. This lack of opportunity will affect their well-being in the host country (Franks, Gawn \& Bowden, 2007).

However, greater access to care alone is unlikely to alleviate the burden of these disorders among refugees. Global evidence is growing that adverse social and economic conditions, including pandemics, have a strong effect on the risk of disease (Neubauer, Schmidt, Kramer\& Schmiedek, 2020). For the well-being of refugees, specific policies and plans related to resettlement arrangements and targeted programs and welfare provisions are also important, hence relevant to country plans to achieve several of the SDGs (World Psychiatric Association (WPA), 2017). This study therefore recognizes the importance of recognizing factors that lead to their positive social adaptation and inclusion, in order to reduce the effects of negative mental health on refugees. This is because migrant and refugee inclusion programs can have very positive impacts on host countries (see Fulbright, 1976).

Based on Ward and Kennedy's (1993) social skills framework and other related personal values and well-being literature, this research uses data from a group of refugees in Malaysia to answer one main question: How do the personal values of refugees affect their adaptation and well-being? This is because many governments and social advocacy projects have been the key inspiration for building the bridges of international encounters and understanding across countries (Pitts, 2005). In fact, some countries have introduced security and suspension of deportation by granting an extended right to remain for a certain time period, which is related to increased psychological pressure on asylum seekers in the face of adverse decisions by recipient countries (Walther et al, 2020). Further, the growing literature on refugees highlights their losses, difficulties with adaptation and stressors that currently contribute to the conceptualization of refugees as one of the most vulnerable populations among all immigrants (Berry et al, 1997). This study aims to explore the attempts of refugees to acculturate and integrate into a new society and to become more prepared to address their recent experiences during the pandemic.

\section{The Reciprocal Connotation between Personal Values, Sociocultural Adaptation and Subjective Well-Being}

Values are motivational goals that affect behaviors, behaviours and assessments (Fischer \& Boer, 2016). The value theory of Schwartz (Schwartz \& Bardi, 2001; Schwartz \& Bilsky, 1990), defines values as positive, trans-situational objectives of varying significance, which serve as action guidelines. Pecoraro, Manatschal, Green \& Wanner (2019) study suggested that values motivate adaptation assessments is important because it will affect well-being.

Values affect human actions, motivation, and objectives (Ferssizidis et al., 2010; Homer \& Kahle, 1988). In other words, personal values represent what is primarily important to an individual and thus form a core part of the identity of an individual that directs their behavior (Jamaludin, Sam, Sandal \& Adam, 2016). In addition, studies by Fischer and Boer (2016), 
Sortheix and Lönnqvist (2014), Bobowik et al (2011) and Sagiv and Schwartz (2000) show that there is an increase in interest in the link between personal values and well-being. According to Sagiv and Schwartz (2000); Sortheix and Lönnqvist (2014); Sortheix and Lönnqvist (2015); and Bobowik et al. (2011), the subjective well-being of a person can depend on the priority values of the individual. Subjective well-being encompasses positive and negative consequences of psychological well-being together (Diener, 2009). Psychological adaptation and sociocultural adaptation have been argued to be linked; their correlations have been reported to be in the range of (Berry, 2003). In addition, Ward and Kennedy (1999) find that the effects of psychological and sociocultural adaptation are positively associated with psychological and sociocultural adaptation. It was also found that the strength of the psychological and sociocultural adaptation connection was positively linked to the degree of cultural closeness and integration in the social host community (Ward, 1999; Ward \& Kennedy, 1996; Ward, Okura, Kennedy, \& Kojima, 1998; Ward \& Rana-Deuba, 1999). Although the researcher admits that the relationship could be reciprocal between aspects of sociocultural adaptation and aspects of psychological adaptation, the researcher restricts the hypothesis in this analysis to the flow of effects from sociocultural adaptation to psychological adaptation, as indicated by the researcher (Ouarasse \& Vijver, 2005).

Therefore, at the time of COVID19, we hypothesized that values could account for some of the predictive variance associated with sociocultural adaptation and the subjective well-being of refugees. In addition, Bobowik et al. (2011) proposed that the impact of values across societies can be driven by contextual demands in a practical value-fit pattern that emphasizes effective social and economic adaptation (Sortheix \& Lönnqvist, 2014; Sortheix \& Lönnqvist, 2015).

A refined theory was introduced by Schwartz et al. (2012), which separated 19 more precisely defined values clustered in the same 4 higher order value. These higher order values are: selfenhancement, intended as power over people and achievement of personal success by demonstrating competence according to social standards; openness to change, defined as the degree to which people are driven in uncertain directions to pursue their own intellectual and emotional interests, self-transcendence refers to the importance given to concern for others, broadly defined, and spiritual life, meaning in life, unity with nature, and inner harmony; preservation, which combines conformity, security, and tradition, and refers to the extent to which people are motivated to preserve the status quo and the certainty it provides (Schwartz, 1992; Cieciuch et al., 2014).

According to the theory of the Schwartz value (Schwartz, 1992), two essential bipolar dimensions structure these four values. In terms of the degree to which they encourage people to seek their independence in unexpected ways versus preserving the status quo in relationships with others, organizations, and practices, the first dimension is called openness to change versus conservation and community values. In contrast to universalism and benevolence ideals, the second fundamental component is called self-enhancement versus self-transcendence and incorporates selfish concerns, achievement of power and hedonism. The focus of this research will be on the later.

Finally, the theory specifies that personal oriented values are self-enhancement and openness to change, as they relate to individual aspects, while social focused values are conservation 
and self-transcendence, as they deal with the relationships between the individual and his or her social background and environment (Schwartz, 1992; Cieciuch et al., 2014). Recent research has shown us that openness to change and principles of self-transcendence associate more strongly with subjective well-being (Schwartz \& Sortheix, 2018).

Following the assertion by Pecoraro, Manatschal, Green \& Wanner, (2019), Schwartz, (1992), Cieciuch et al., (2014), Sortheix and Lönnqvist (2014) and Yijälä, Lönnqvist, Jasinskaja-Lahti \& Verkasalo (2012), we also argue that anticipated socio-cultural adaptation will predict not only personal values, but also beliefs about the value climate of the host society. If a typical host country member is expected to be helpful, friendly, and broad-minded (Schwartz, 1992), i.e. as adhering to values of self-transcendence, then immigrants may expect fewer difficulties in adapting, particularly at the time of the pendamic COVID19. On the contrary, it could be expected that perceiving hosts to emphasize self-enhancement values, which refer to adherence to achievement and power (Schwartz, 1992), would predict more anticipated difficulties in adaptation.

We therefore believe that during the COVID19 pandemic, self-transcendence would be positively linked to sociocultural adaptation and well-being for refugees. We also postulated that sociocultural adaptation and well-being would be negatively related to selfenhancement. By looking at the relationship between self-enhancement versus selftranscendence-sociocultural adaptation-subjective well-being, this study will further examine self-enhancement versus self-transcendence values.

\section{Hypotheses}

The present study sought to understand, based on the literature, the independent contributions made in predicting subjective well-being through self-transcendence, selfenhancement and sociocultural adaptation. As control variables, age and gender were used. The following theories have been tested:

H1. Refugees' self-transcendence has a positive and significant influence with subjective well-being

H2. Refugees' self-enhancement has a negative and significant influence with subjective well-being

H3. Refugees' sociocultural adaptation has a positive and significant influence with subjective well-being.

H4. Refugees' sociocultural adaptation will mediate the influence between selftranscendence and subjective well-being

\section{Methodology \\ Participants}

The sample consisted of 381 individuals of pure Afghan's parentage. Number sampling frame is available in the country that would allow exact proportional representation of Afghan's refugees in Malaysia. In terms of gender distribution, there was an even split between female and male refugees 42 percent females vs. 58 percent males. For age, majority (more than 50 percent) was between 26 to 30 years' old. Thus, we believe that in this study, age and gender are present in the sample in ways that would provide the necessary variation to study psychosocial-related variables. 


\section{Instruments}

\section{Subjective well-being}

Subjective well-being was assessed throughout samples using an affect balance measure together with life satisfaction. To measure this, the Satisfaction with Life Scale (SWLS) developed by Diener, Emmons, Larsen, and Griffin (1985) and the Positive and Negative Affect Schedule (PANAS) developed by Watson, Clark, and Tellegen (1988) were used. Alpha value for subjective well-being (0.70).

\section{Sociocultural adaptation}

Following Ward and Kennedy (1999), we used only 23 items from the 40 items scale of culture-general items appropriate for refugees. The overall degree of sociocultural adaptation was calculated by the average scores of the products. Higher scale values demonstrated greater complexity in socio-cultural adaptation. We reversed scores on the items for clearer analysis of the findings, however, so that higher scores suggested better socio-cultural adaptation. Cronbach alpha $=0.91$.

\section{Personal values}

The 40-item PVQ or PVQ-40 was used in the present study. The PVQ-40 comprises 10 subscales that measure the 10 value types. Each PVQ item comprises a two-sentence short verbal portrayal of a person's goals or aspirations (Schwartz, 2005), on a 6-point scale (1=not like me at all to $6=$ very much like me). We computed scores for each of the two higher order values (self-enhancement, and self-transcendence) by averaging responses to the items from the values that constitute the higher order values. We corrected the value indices by centering each individual's responses on his or her mean response to all value items (Schwartz, 2003, 2005; Schwartz, Verkasalo, Antonovsky, \& Sagiv, 1997). Alpha value for selfenhancement (0.73) and self-transcendence (0.74).

\section{Results}

The related statistical analysis of hypotheses was checked before performing a hierarchical multiple regression. First, considering the three independent variables to be used in the study, a sample size of $n=378$ refugees was considered sufficient (Tabachnick \& Fidell, 2001). Among the independent variables, the assumption of singularity was also satisfied (selftranscendence, self-enhancement and sociocultural adaptation). An review of correlations (see Table 1) showed that there were no strongly correlated variables. To determine the internal consistency of multiple measures for each construct, a reliability test was performed. The internal reliability was verified by Cronbach Alpha values of 0.70-0.91.

Table 1

Correlation for the variables (Self-Transcendent vs Self Enhancement)

\begin{tabular}{lcccccc}
\hline Correlation & $\mathbf{1}$ & $\mathbf{2}$ & $\mathbf{3}$ & $\mathbf{4}$ & $\mathbf{5}$ & $\mathbf{6}$ \\
\hline 1. Gender & - & & & & & \\
2. Age & $.214^{* *}$ & - & & & & \\
3. Subjective well-being & .032 & .026 & - & & & \\
4. Self- Enhancement & .013 & -.071 & $.205^{* *}$ & - & & \\
5. Self- Transcendence & -.072 & $-.224^{* *}$ & $.334^{* *}$ & .117 & - & \\
6. Sociocultural adaptation & $-.174^{*}$ & $-.197^{* *}$ & $.176^{*}$ & $.222^{* *}$ & $.358^{* *}$ & - \\
\hline
\end{tabular}

Note. 
**. Correlation is significant at the 0.01 level (2-tailed).

*. Correlation is significant at the 0.05 level (2-tailed).

The skewness and kurtosis of all regression models in this study indicated that the assumptions of normality were all satisfied (Hair, Black, Babin, \& Anderson, 2010; Pallant, 2013). In addition, the Durbin-Watson value in regression models indicates no autocorrelation. Both collinearity statistics (i.e. tolerance and VIF) were within agreed limits, suggesting that it was considered that the presumption of no multicollinearity was met (Hair et al., 2010). No multivariate outliers for the data set were suggested for an analysis of the Mahalanobis Distance scores.

As the dependent variable, a three-stage hierarchical multiple regression was performed between the independent variables with subjective well-being. At stage one of the regressions, gender and age were introduced as the control variables. At stage two, selfenhancement and self-transcendence were entered next. Lastly, at stage three, selfenhancement self-transcendence and sociocultural adaptation were entered. In this order, the relationship variables were entered, as it seemed chronologically possible based on the literature based on Pecoraro, Manatschal, Green \& Wanner (2019), Schwartz, (1992), Cieciuch et al., (2014), Sortheix and Lönnqvist (2014) and Yijälä, Lönnqvist, Jasinskaja-Lahti \& Verkasalo (2012).

Table 2

Results for hierarchical regression

\begin{tabular}{|c|c|c|c|c|c|c|c|c|c|}
\hline \multicolumn{2}{|c|}{$\begin{array}{l}\text { Hierarchical } \\
\text { regression }\end{array}$} & \multirow[t]{2}{*}{$\beta$} & Sig. & \multirow[t]{2}{*}{$\begin{array}{c}\text { Toleranc } \\
\mathrm{e}\end{array}$} & \multirow[t]{2}{*}{ VIF } & \multirow{2}{*}{$\frac{\mathrm{R}}{.037}$} & \multirow{2}{*}{$\begin{array}{c}\mathrm{R} \\
\begin{array}{c}\text { Squar } \\
\mathrm{e}\end{array} \\
.001\end{array}$} & \multirow{2}{*}{$\begin{array}{c}\Delta \mathrm{R} \\
\text { Squar } \\
\mathrm{e} \\
.001\end{array}$} & \multirow{2}{*}{$\begin{array}{c}\begin{array}{c}\text { Durbin- } \\
\text { Watson }\end{array} \\
1.97\end{array}$} \\
\hline 1 & (Constant) & & .00 & & & & & & \\
\hline & & & 0 & & & a & & & \\
\hline & Gender & .03 & .70 & .954 & 1.0 & & & & \\
\hline & & & 8 & & 5 & & & & \\
\hline & Age & .02 & .78 & .954 & 1.0 & & & & \\
\hline & & & 9 & & 5 & & & & \\
\hline \multirow[t]{11}{*}{2} & (Constant) & & .00 & & & .292 & .085 & .084 & \\
\hline & & & 0 & & & b & & & \\
\hline & Gender & -.01 & .86 & .911 & 1.1 & & & & \\
\hline & & & 2 & & 0 & & & & \\
\hline & Age & .02 & .80 & .948 & 1.0 & & & & \\
\hline & & & 6 & & 6 & & & & \\
\hline & Self- & .09 & .24 & .828 & 1.2 & & & & \\
\hline & Enhancement & & 2 & & 1 & & & & \\
\hline & Self- & $.25 * *$ & .00 & .859 & 1.1 & & & & \\
\hline & Transcendenc & & 1 & & 6 & & & & \\
\hline & $\mathrm{e}$ & & & & & & & & \\
\hline \multirow[t]{2}{*}{3} & (Constant) & & .16 & & & .501 & .251 & .165 & \\
\hline & & & 8 & & & c & & & \\
\hline
\end{tabular}




$\begin{array}{lcccc}\text { Gender } & .00 & .94 & .890 & 1.1 \\ & & 7 & & 2 \\ \text { Age } & .11 & .12 & .895 & 1.1 \\ & & 1 & & 2 \\ \text { Self- } & .06 & .41 & .784 & 1.2 \\ \text { Enhancement } & & 5 & & 8 \\ \text { Self- } & .26^{* *} & .00 & .828 & 1.2 \\ \text { Transcendenc } & * & 0 & & 1 \\ \text { e } & & & & \\ \text { Sociocultural } & .22^{* *} & .00 & .862 & 1.1 \\ \text { adaptation } & & 1 & & 6\end{array}$

Note. ${ }^{*} p<.05 .{ }^{* *} p<.01 .{ }^{* * *} p<.001$.

Analysis in Table 2 indicates that in stage 1, age and gender did not contribute significantly to the regression model, $F(2,192)=0.134, p>.001$, and accounted for only $1.0 \%$ of the variation in subjective well-being for refugees. Introducing self-enhancement and self- transcendence to the regression model explained an additional $8.5 \%$ of variation in subjective well-being, and this change in $\mathrm{R}^{2}$ was significant, $F(4,190)=4.44, \mathrm{p}<.01$. Finally, adding sociocultural adaptation in stage three, explained a total of $16.5 \%$ of the variation in subjective well-being; this change in $R^{2}$ square was also significant, $F(8,186)=7.78, p<.001$.

To summarize, when all three independent variables were included in stage three of the regression model, neither age, gender nor self-enhancement $(\mathrm{H} 2)$ were significant predictors of subjective well-being. Results also show that $\mathrm{H} 1$ and $\mathrm{H} 3$, self-transcendence $(\beta=0.26, p<$ $.001)$, and sociocultural adaptation $(\beta=0.22, p<.01)$, were significant predictors of subjective well-being. Self-transcendence, contribute more than sociocultural adaptation in influencing subjective well-being. This accounted for a total of $25.1 \%$ of the variance in subjective wellbeing.

Next, in assessing $\mathrm{H} 4$, the hierarchical multiple regression technique is used to examine whether the mediating variable (sociocultural adaptation) mediate or partially mediate the effects of independent variables (self-transcendence) on the dependent variable (subjective well-being). Partial mediation is an effect when a relationship between a predictor and an outcome is decreased, according to Hair et al. (2006), but it remains relevant when a mediator is also used as an additional predictor. Complete mediation occurs if after a mediator is entered as an additional mediator, a correlation between a predictor and an outcome variable becomes insignificant (Hair et al., 2006).

For $\mathrm{H} 4$, first a significant effect of the independent variable (self-transcendence) on the dependent variable (subjective well-being) is clearly evident from the regression. A important shift is revealed by the inclusion of the mediating variable sociocultural adaptation in the final stage of the regression. In conclusion, the correlation between self-transcendence and subjective well-being remains essential and strengthened once sociocultural adaptation is included as additional predictors in the model, so we can conclude that mediation is not assisted (Aiken and West 1991; Bryk and Raudenbush 1992; and Hair et al. 2006). Therefore, $\mathrm{H} 4$ is not supported. 


\section{Discussion}

The terms of working hypothesis of this study was that the personal values and socio-cultural adaptation of refugees can affect their well-being at the time of the pandemic, and that the results may have some implications for the social inclusion programs of refugees, which may contribute to the positive mental health and overall social harmony of the country concerned in meeting the SDG 3 agenda.

The findings showed that gender and age did not substantially contribute to the model of regression. Self-transcendence was the most significant indicator of subjective well-being for refugees from Afghanistan ( $\mathrm{H} 1)$. Self-transcendence tends to effect subjective well-being rather than sociocultural adaptation (H3). Self-enhancement $(\mathrm{H} 2)$, however, was not a major predictor of subjective well-being. Next the hierarchical multiple regression method is used in the evaluation of $(\mathrm{H} 4)$ to examine whether the mediating variable (sociocultural adaptation) mediates the effects of independent variables (self-transcendence) on the dependent variable (subjective well-being). Results suggested that the mediation is not supported.

The research findings on refugees offered some support for the proposal derived from the principle of self-determination (Ryan and Deci, 2001) that some principles may be considered to enhance personal well-being uniformly, while others undermine it. Our findings concerning H1 were in line with the literature (see Hwang, Tu, \& Chan, 2019; Sortheix and Lönnqvist, 2014). Further, Malaysia is ranked at the top for healthcare responses during COVID19, based on the latest WHO survey (2020). It is therefore consistent with the suggestion by Sortheix and Lönnqvist (2014) that for countries with high HDI, social-focused values (selftranscendence) contribute positively to subjective well-being. In addition, these principles inspire prosocial actions and lead to social capital and confidence (Helliwell \& Putnam, 2004; Devos, Spini, \& Schwartz, 2002). In other words, in order to feel good about themselves, Afghan refugees tend to prefer circumstances that foster selflessness, understanding, appreciation, tolerance and security for the welfare of all people and for nature. Refugees recognize that migration is a phase in which they abandon their home countries' experiences and practices by creating an identity that is more concerned with group identity than with individual identity (Nabi, 2014). Moreover, refugee opinions are linked to social norms and optimistic perceptions, thus reducing the stigma of their self-conception as refugees (Walther, Fuchs, Schupp, \& von Scheve, 2020). In other words, refugees who benefit from their stay in Malaysia emphasize the clean essence of the country and its welfare society. When trying to improve the social inclusion and well-being of refugees at the time of COVID19, highlighting these aspects may be significant. When enforcing legislation and policies, we suggest that stakeholders working with refugees concentrate more on selftranscendence (i.e. fostering selflessness, understanding, respect, tolerance and security for the welfare of all people).

For $\mathrm{H} 2$, our results suggest that self-enhancement is not related to better well-being in refugees. These findings are generally concordant with the literature on healthy values (Kasser and Ahuvia 2002; Vansteenkiste et al. 2006; Jamaludin, Sam, Sandal \& Adam, 2016). The result indicates that in the era of the pandemic, individuals high on power and achievement-value orientations may be less concerned with subjective well-being, and their concern about well-being may be less important. In addition, substantial support for the 
proposed structure has been found worldwide (see Schwartz, 2011). In Western cultures, however, support for the theory has proved to be much stronger (Hitlin and Piliavin, 2004). Relationship decisions should have a sound theoretical foundation and a clear appreciation of the strengths and weaknesses of statistical indices (Huberty and Morris, 1988). We therefore recommend that further analysis should be carried out to investigate the relationship until it is possible to draw a firm conclusion.

Next, our $\mathrm{H} 3$ findings showed that at the time of the pandemic, socio-cultural adaptation had a beneficial impact on subjective well-being. Persons who consider themselves to be socially competent often feel secure in their comprehension of the community in a different society, according to Sam et al. (2015). It should be noted that the biggest obstacle for refugees in adapting to a new society is more to build social relations with the local community (Nabi, 2014). Feelings of alienation are known to be a factor that increases psychological tension during the process of cultural adaptation (Huang, Appel \& Al., 2011). Therefore, our results with reference to refugees seem fair. In addition, communication skills and language abilities are two of the main keys to sociocultural adaptation (Searle \& Ward, 1990; Ward \& RanaDeuba, 1999). Within this background, the researchers think it would be a big breakthrough to develop Malaysian language skills. Industry players working with refugees should establish programs that are directly linked to enhanced engagement with host nationals, resulting in a decrease in problems of sociocultural adaptation, especially when coping with uncertainty at the time of COVID19. It could lead to improved intercultural comprehension and decreased feelings of strangeness and social distance. In addition, given that many socio-cultural issues relate to daily life, such as seeking directions and using the public transit system, an easy-toprepare knowledge kit can be a great help for refugee adjustment. In addition, as a result of these different factors that affect their transition to the current situation, lack of education and prejudice are part of what refugees think about most (Nabi, 2014). In addition, it may be necessary for counselors and mental health practitioners to evaluate weak sociocultural integration while dealing with refugees, as it may be an early indication of later illness. In determining the causes of adaptation issues and in learning more about the functioning of refugees, it could be a simple thermometer.

Finally, $\mathrm{H} 4$ dealt with the role of sociocultural adaptation as a mediator of self-transcendence towards subjective well-being. We considered the pattern of causal relationships to be inconsistent with what could logically be predicted, as outlined in the results section (i.e., Mokhothu \& Callaghan, 2018). Mediation experiments failed to confirm a major reduction in the direct effect when the indirect effect was included in the tests. In particular, human rights are a matter, according to Hartley and Pedersen (2019), such as having the right to live in peace, a place to live and work so that they can give their families a decent life, is a way to build more successful welfare. This finding suggests that the contribution of selftranscendence to subjective well-being may not inherently be through the channel of sociocultural adaptation. This indicates that self-transcendence has a direct connection with the well-being of Afghan refugees. Socio-cultural adaptation is required to work in the silo in this report. For the appropriate authority, this information is taken to be significant (i.e., UNHCR). If the authority can inspire or motivate refugees to engage in activities that emphasize respect for others' welfare and interests, it could help enhance refugees' social inclusion. 
We suggest that while the emphasis of this paper is on the sociocultural context, other factors of variation also play important roles in the relationship between personal values and wellbeing. In addition to the sociocultural impact mediator mentioned here the relationships between personal values and metal health results may be further mediated by other factors and characteristics. In this study, for example, Afghan refugees may differ in reactivity to psychobiological stress, vulnerability and coping in response to psychosocial stressors, and tendency during the pandemic period for mental and physical illnesses. Moreover, although this research focuses on the concept of sociocultural meaning, the conceptualization and variable collection of personal values and subjective well-being should also be subject to rigorous analysis. In order to fully understand the role of personal values in population epidemiology, it is important to recognize both sociocultural and other concerns as an impact enhancer. Nevertheless, while this study found very little evidence for the relationship between self-enhancement-sociocultural adaptation-subjective well-being, we conclude that dismissing the possible relationship as non-existent might be premature. A research by Eggerman \& Panter-Brick (2010) shows that as families struggle to stick to their beliefs in the face of pronounced social disparities detrimental to well-being, sources of entrapment for Afghans. A strong, policy-relevant message was therefore expressed by Afghans: there is no health without mental health, no family unity without jobs, integrity and a functioning economy (Eggerman \& Panter-Brick, 2010). Therefore more research on the effect of strengthening one's own personal interests (even at the detriment of others on their wellbeing is required. In addition, more research may be needed on alternative higher order values such as openness to change vs. conservativeness, as well as peculiar features of the samples under investigation to better understand the relationship.

To sum up, our studies of how self-improvement vs self-transcendence, socio-cultural adaptation and subjective well-being indicate a pattern that is generally correct. Nevertheless, some of the conflicting hypothesis results need further verification.

\section{Limitations and Recommendations}

A natural question is whether we can generalize our findings to other groups of refugees or refugees in other Asian countries. To give a clear answer to this issue, we think it is too early, except to suggest that more studies are needed. We suggest that more heterogeneous samples, such as refugees from other places, should be used in future studies. In this research, subjective well-being was assessed during the stay of refugees in Malaysia during the time of the pandemic. We do not know if these findings will be maintained in various countries where the government is taking a different approach to combating COVID19. We assume, however that research investigating the subjective well-being of refugees during and post-COVID would go a long way in giving us a deeper understanding of this phenomenon.

We suggest that these results can be further evolved to provide new insights into subjective well-being research beyond personal beliefs and socio-cultural adaptation solely as predictors. While each of these results represents a significant contribution to the understanding of the well-being of refugees, considerable research is still needed, given the competitive environment in which they are currently immersed, to clarify relational interactions in this context. 


\section{Conclusion}

To conclude, the findings showed that gender and age did not substantially contribute to the model of regression. Self-transcendence was the most significant indicator of subjective wellbeing for refugees from Afghanistan (H1). Self-transcendence tends to effect subjective wellbeing rather than sociocultural adaptation $(\mathrm{H} 3)$. Self-enhancement $(\mathrm{H} 2)$, however, was not a major predictor of subjective well-being. Next the hierarchical multiple regression method is used in the evaluation of $(\mathrm{H} 4)$ to examine whether the mediating variable (sociocultural adaptation) mediates the effects of independent variables (self-transcendence) on the dependent variable (subjective well-being). Results suggested that the mediation is not supported. To sum up, our studies of how self-improvement vs self-transcendence, sociocultural adaptation and subjective well-being indicate a pattern that is generally correct. Nevertheless, some of the conflicting hypothesis results need further verification.

To sum, direct value-sociocultural adaptation-subjective well-being associations are explained well by theorizing based on combining the social-versus person-focus of values. These associations, however, differ across contexts. We believe in the time of pandemic, the context may refer to family, friends, neighbourhood, support, society, and more. We can understand the variation of results in the associations of particular values with subjective well-being is highly influence by characteristics of the context that promote or block attainment of these values especially during COVID19 pandemic. We anticipate many new insights with the recent flourishing of research on personal value-subjective well-being relations, and with the additional inclusion of sociocultural adaptation.

\section{References}

Ahmad, A., Mueller, C., \& Tsamakis, K. (2020). Covid-19 pandemic: a public and global mental health opportunity for social transformation?. BMJ (Clinical research ed.), 369, m1383. https://doi.org/10.1136/bmj.m1383

Ames, D. L., \& Fiske, S. T. (2010). Cultural neuroscience. Asian journal of social psychology, 13(2), 72-82.

Becker, J. R., Engelbrecht, A., Boonzaaier, M., Finch, J. D., Meiring, D., \& Louw, G. (2017). The measurement of values: A psychometric evaluation of the Schwartz Value Survey in the South African context. Management Dynamics: Journal of the Southern African Institute for Management Scientists, 26(2), 21-41.

Berry, J. W. (2005). Acculturation: Living successfully in two cultures. International Journal of Intercultural Relations, 29(6), 697-712.

Berry, J. W. (2003). Conceptual approaches to acculturation. In K. M. Chun, P. B.Organista, \& G. Marin (Eds.), Acculturation: Advances in theory, measurement, and applied research (pp. 17-39). Washington DC: American Psychological Association.

Berry, J. W. (1997). Immigration, acculturation and adaptation. Applied Psychology: An International Review, 46, 5-34.

Bobowik, M., Basabe, N., Páez, D., Jiménez, A., \& Bilbao, M. Á. (2011) Personal values and well-being among Europeans, Spanish natives and immigrants to Spain: does the culture matter? J Happiness Stud 12(3):401-419

Boer, D., \& Fischer, R. (2013). How and when do personal values guide our attitudes and sociality? Explaining cross-cultural variability in attitude-value linkages. Psychological bulletin, 139(5), 11-13. 
Cieciuch, J., Davidov, E., Vecchione, M., Beierlein, C., \& Schwartz, S. H. (2014). The crossnational invariance properties of a new scale to measure 19 basic human values: $A$ test across eight countries. Journal of Cross-Cultural Psychology, 45(5), 764-776.

Diener, E., Emmons, R. A., Larsen, R. J., \& Griffin, S. (1985). The Satisfaction with Life Scale. Journal of Personality Assessment, 49(1), 71-75. doi: 10.1207/s15327752jpa4901_13

Diener, E. (2000). Subjective well-being: The science of happiness and a proposal for a national index. American Psychologist, 55, 34-43. https://doi.org/10.1037/0003066X.55.1.34.

Diener, E. (2009). Subjective well-being. In The science of well-being (pp. 11-58). Springer, Dordrecht.

Devos, T., Spini, D., \& Schwartz, S. H. (2002). Conflicts among human values and trust in institutions. British Journal of Social Psychology, 41(4), 481-494.

Eggerman, M., \& Panter-Brick, C. (2010). Suffering, hope, and entrapment: Resilience and cultural values in Afghanistan. Social science \& medicine, 71(1), 71-83.

Franks, W., Gawn, N., \& Bowden, G. (2007). Barriers to access to mental health services for migrant workers, refugees and asylum seekers. Journal of Public Mental Health, 6(1), 33.

Fischer, R., \& Boer, D. (2016) Values: the dynamic nexus between biology, ecology and culture. Current Opinion Psychology 8:155-160

Fulbright, J. W. (1976). The most significant and important activity I have been privileged to engage in during my years in the Senate. The Annals of the American Academy of Political and Social Science, 424(1), 1-5.

Ferssizidis, P., Adams, L. M., Kashdan, T. B., Plummer, C., Mishra, A., \& Ciarrochi, J. (2010). Motivation for and commitment to social values: The roles of age and gender. Motivation and Emotion, 34(4), 354-362.

Gibson, J. J. (1977). The theory of affordances. Hilldale, USA, 1(2).

Hagendoorn, L. (1991). Determinants and dynamics of national stereotypes. Politics \& the Individual.

Hartley, L., \& Pedersen, A. (2019). "They are humans and humanity comes first": The function of attitudes towards people seeking asylum in Australia. Australian Community Psychologist: The official journal of the APS College Of Community Psychologists. 30 (1): pp. 51-64.

Hair, J. F., Black, W. C., Babin, B. J., \& Anderson, R. E. (2010) Multivariate data analysis: A global perspective, 7th edition. Pearson Prentice Hall, New Jersey

Henrich, J., Heine, S. J., \& Norenzayan, A. (2010). The weirdest people in the world?. Behavioral and brain sciences, 33(2-3), 61-83.

Helliwell, J. F., \& Putnam, R. D. (2004). The social context of well-being. Philosophical Transactions of the Royal Society of London. Series B: Biological Sciences, 359(1449), 1435-1446.

Hitlin, S., \& Piliavin, J. A. (2004). Values: Reviving a dormant concept. Annual Review of Sociology, 30: 359-393.

Huberty, C. J., \& Morris, J. D. (1988). A single contrast test procedure. Educational and Psychological Measurement,48: 567-578.

Hwang, H. L., Tu, C. T., \& Chan, H. S. (2019). Self-transcendence, caring and their associations with well-being. Journal of advanced nursing, 75(7), 1473-1483.

Homer, P. M., \& Kahle, L. R. (1988) A structural equation test of the value-attitudebehavior hierarchy. J Pers Soc Psychol 54(4):638-646 
Huang, B., Appel, H., \& Ai, A. L. (2011). The effects of discrimination and acculturation to service seeking satisfaction for Latina and Asian American women: implications for mental health professions [published correction appears in Soc Work Public Health. 2011 Mar;26(2):230]. Soc Work Public Health. 26 (1), 46-59. doi:10.1080/10911350903341077

Jamaludin, N. L., Sam, D. L., Sandal, G. M., \& Adam, A. A. (2016). Personal values, subjective well-being and destination-loyalty intention of international students. Springerplus, $5(1), 720$.

Kasser, T., \& Ahuvia, A. (2002). Materialistic values and well-being in business students. European journal of social psychology, 32(1), 137-146.

Lau, W., \& Thomas, T. (2008). Research into the psychological well-being of young refugees. International Psychiatry. 5 (3). 60-62. 10.1192/S1749367600002071.

Linley, P. A., \& Joseph, S. (2004). Applied positive psychology: A new perspective for professional practice. Positive psychology in practice, 3-12.

Mokhothu, T. M., \& Callaghan, C. W. (2018). The management of the international student experience in the South African context: The role of sociocultural adaptation and cultural intelligence. Acta Commercii, 18(1), 1-11.

Nabi, F. (2014). The Impact of the Migration on Psychosocial Well-Being: A Study of Kurdish Refugees in Resettlement Country. Journal Community Medical Health Education 4:273. doi:10.4172/2161-0711.1000273

Neubauer, A., Schmidt, A., Kramer, A., \& Schmiedek, F. (2020). A Little Autonomy Support Goes a Long Way: Daily Autonomy-Supportive Parenting, Child Well-Being, Parental Need Fulfillment, and Change in Child, Family, and Parent Adjustment Across the Adaptation to the COVID-19 Pandemic.

Nesterko, Y., Jäckle, D., Friedrich, M., Holzapfel, L., \& Glaesmer, H. (2020). Prevalence of posttraumatic stress disorder, depression and somatisation in recently arrived refugees in Germany: an epidemiological study. Epidemiology and Psychiatric Sciences, 29.

Norenzayan, A., \& Heine, S. J. (2005). Psychological universals: What are they and how can we know?. Psychological bulletin, 131(5), 763.

Ouarasse, O. A., \& Van de Vijver, F. J. (2005). The role of demographic variables and acculturation attitudes in predicting sociocultural and psychological adaptation in Moroccans in the Netherlands. International Journal of Intercultural Relations, 29(3), 251-272.

Otu, A., Charles, C. H., \& Yaya, S. (2020). Mental health and psychosocial well-being during the COVID-19 pandemic: the invisible elephant in the room. International Journal of Mental Health Systems, 14(1), 1-5.

Pallant, J. (2013). SPSS survival manual. McGraw-Hill Education (UK).

Pecoraro, M., Manatschal, A., Green, E. G., \& Wanner, P. (2019). Does integration policy improve labour market, sociocultural and psychological adaptation of asylum-related immigrants? Evidence from Sri Lankans in Switzerland (No. 19-08). IRENE Institute of Economic Research.

Pitts, M. J. (2005). The role of communication in cross-national adjustment and identity transitions among student sojourners. The Pennsylvania State University, USA.

UNHCR. (2019). Global Report 2019. Retrieved June 30, 2020, from https://www.unhcr.org/globalreport2019/

UNHCR. (2020). UNHCR urges prioritization of mental health support in coronavirus response. Retrieved June 30, 2020, from https://www.unhcr.org/en- 
my/news/press/2020/5/5ebcfd784/unhcr-urges-prioritization-mental-healthsupport-coronavirus-response.html

Roccas, S., Sagiv, L., Schwartz, S. H., \& Knafo, A. (2002). The big five personality factors and personal values. Personality and social psychology bulletin, 28(6), 789-801.

Ryan, R. M., \& Deci, E. L. (2001). On happiness and human potentials: A review of research on hedonic and eudaimonic well-being. Annual review of psychology, 52(1), 141-166.

Rienties, B., Luchoomun, D., \& Tempelaar, D. (2013). Academic and social integration of Master students: A cross-institutional comparison between Dutch and international students. Innovations in Education and Teaching International, 51, 130-141.

Safak-Ayvazoglu, A., \& Kunuroglu, F. (2019). Acculturation experiences and psychological well-being of Syrian refugees attending universities in Turkey: A qualitative study. Journal of Diversity in Higher Education.

Sagiv, L., Schwartz, S. H. (2000) Value priorities and subjective well-being: direct relations and congruity effects. Eur J Soc Psychol 30(2):177-198

Sagiv, L., \& Schwartz, S. H. (1995). Value priorities and readiness for out-group social contact. Journal of personality and social psychology, 69(3), 437.

Statista. (2020). Number of confirmed COVID-19 cases per state in Malaysia as of June 25, 2020. Retrieved June 30, 2020, from

https://www.statista.com/statistics/1107426/malaysia-covid-19-confirmed-casesby-state/

Schwartz, S. H. (1992). Universals in the content and structure of values: Theoretical advances and empirical tests in 20 countries. Advances in experimental social psychology, 25(1), 1-65.

Schwartz, S. H. (2012). An overview of the Schwartz theory of basic values. Online Readings in Psychology and Culture 2(1):11. doi:10.9707/2307-0919.1116

Schwartz, S. H., Bilsky, W. (1990). Toward a theory of the universal content and structure of values: extensions and cross-cultural replications. J Pers Soc Psychol 58(5):878-891

Schwartz, S. H., Bardi, A. (2001). Value hierarchies across cultures taking similarities perspective. J Cross Cult Psychol 32(3):268-290

Schwartz, S. H., \& Sortheix, F. (2018). Values and subjective well-being. Handbook of wellbeing.

Schwartz, S. H., Verkasalo, M., Antonovsky, A., \& Sagiv, L. (1997). Value priorities and social desirability: Much substance, some style. British Journal of Social Psychology, 36, 318. doi:10.1111/j.2044-8309.1997.tb01115.x

Schwartz, S. H. (2003). A proposal for measuring value orientations across nations. Questionnaire package of the european social survey, 259(290), 261.

Shweder, R. A. (1997). The surprise of ethnography. Ethos, 25(2), 152-163.

Searle, W., \& Ward, C. (1990). The prediction of psychological and sociocultural adjustment during cross-cultural transitions. International journal of intercultural relations, 14(4), 449-464.

Sortheix, F. M., Lönnqvist, J-E. (2014). Personal value priorities and life satisfaction in Europe the moderating role of socioeconomic development. J Cross Cult Psychol 45(2):282299

Sortheix, F. M., \& Lönnqvist J.-E. (2014). Personal value priorities and life satisfaction in Europe: The moderating role of socio-economic development. Journal of CrossCultural Psychology, 45, 282-299. doi: 10.1177/0022022113504621 
Sortheix, F. M., Lönnqvist, J. E. (2015). Person-group value congruence and subjective wellbeing in students from Argentina, Bulgaria and Finland: the role of interpersonal relationships. J Community Appl Soc Psychol 25(1), 34-48

Tabachnick, B. G. F., L. S. (2007). Using Multivariate Statistics (5th ed.). Boston: Pearson Education, Inc.

Vansteenkiste, M., Duriez, B., Simons, J., \& Soenens, B. (2006). Materialistic values and wellbeing among business students: Further evidence of their detrimental effect1. Journal of Applied Social Psychology, 36(12), 2892-2908.

Walther, L., Fuchs, L.M., Schupp, J., von-Scheve. C. (2020). Living Conditions and the Mental Health and Well-being of Refugees: Evidence from a Large-Scale German Survey. J Immigrant Minority Health 22, 903-913 (2020). https://doi.org/10.1007/s10903-01900968-5

Ward, C. (1999). Models and measurement of acculturation. In W. J. Lonner, D. L. Dinnel, D. K. Forgas, \& S. Hays (Eds.). Merging past, present and future (pp. 221-230). Lisse, The Netherlands: Swets \& Zeitlinger.

Ward, C., Bochner, S., \& Furnham, A. (2001). The psychology of culture shock (2nd ed.). Philadelphia, PA: Routledge.

Ward, C., \& Kennedy, A. (1996). Before and after cross-cultural transitions: A study of New Zealand volunteers on field assignment. In. H. Grad, A. Blanco, \& J. Georgas (Eds.), Key issues in cross-cultural psychology (pp. 138-154). Lisse, The Netherlands: Swets \& Zeitlinger.

Ward, C., \& Kennedy, A. (1999). The measurement of sociocultural adaptation. International Journal of Intercultural Relations, 23, 659-677.

Ward, C., Okura, Y., Kennedy, A., \& Kojima, T. (1998). The U-curve on trial: A longitudinal study of psychological and sociocultural adjustment during cross-cultural transition. International Journal of Intercultural Relations, 22, 277-291.

Ward C., \& Rana-Deuba, A. (1999). Acculturation and adaptation revisited. Journal of CrossCultural Psychology, 30, 372-392.

Ward, C., \& Kennedy, A. (1993). Psychological and socio-cultural adjustment during crosscultural transitions: A comparison of secondary students overseas and at home. International journal of psychology, 28(2), 129-147.

Ward, C. A., Bochner, S., \& Furnham, A. (2001). The psychology of culture shock. Psychology Press.

Watson, D., Clark, L. A., \& Tellegen, A. (1988). Development and validation of brief measures of positive and negative affect - the Panas scales. J Pers Soc Psychol 54(6):1063-1070. doi:10.1037/0022-3514.54.6.1063

Wickramage, K., Gostin, L. O., Friedman, E., Prakongsai, P., Suphanchaimat, R., Hui, C., \& Harper, D. R. (2018). Missing: where are the migrants in pandemic influenza preparedness plans? Health and human rights, 20(1), 251.

Welzel, C., \& Inglehart, R. (2010). Agency, values, and well-being: A human development model. Social indicators research, 97(1), 43-63.

Welzel, C., Inglehart, R., \& Klingemann, H. D. (2002). Human development as a theory of social change: A cross-cultural perspective [pdf file]. Retrieved 12th March.

World Psychiatric Association (WPA). (2017) http://docs.wixstatic.com/ugd/e172f3_ee6c006149814d2a9fb957a4237e2d60.pdf Accessed 11 June 2019. 
Yijälä, A., Lönnqvist, J. E., Jasinskaja-Lahti, I., \& Verkasalo, M. (2012). Values as predictors of anticipated socio-cultural adaptation among potential migrants from Russia to Finland. Journal of Community \& Applied Social Psychology, 22(2), 95-110. 